\section{All-cause mortality among Japanese-Brazilians according to nutritional characteristics}

\author{
Mortalidade por todas as causas entre nipo- \\ brasileiros de acordo com as características \\ nutricionais
}

Flavia Cincotto Massimino 1 Suely Godoy Agostinho Gimeno 1 Sandra Roberta Gouveia Ferreira 1 Japanese-Brazilian Diabetes Study Group 2

\footnotetext{
${ }^{1}$ Escola Paulista de Medicina, Universidade Federal de São Paulo, São Paulo, Brasil. 2 Outros membros listados ao final do artigo.

Correspondence

F. C. Massimino

Departamento de Medicina Preventiva, Escola Paulista de Medicina, Universidade Federal de São Paulo. Rua Charles Spencer Chaplin 167, apto.21, São Paulo, SP 05642-010, Brasil. fnutricionista@uol.com.br
}

\begin{abstract}
The aim of this study was to verify the association between nutritional variables and mortality in a Japanese-Brazilian cohort. In 1993, 647 subjects were interviewed with food frequency questionnaires and scheduled for physical procedures (weight, height, blood pressure) and biochemical tests (oral glucose tolerance test). Student's t test was used to compare the mean values of target variables between living and deceased subjects. Mortality rate and hazard ratios were obtained (crude and adjusted) according to the nutritional variables. Overall mortality rates were 21.4 and 11.7/1,000 person-years for males and females, respectively. Smoking, diabetes, sedentary lifestyle, hypertension, higher mean age, high blood pressure, high blood glucose, and higher percent weight gain and rate of weight gain were observed in the history of deceased subjects. After adjusting for control variables, an increase was observed in mortality among individuals with lower carbohydrate and cholesterol intake. The results suggest that mortality risk factors like age, chronic diseases, sedentary lifestyle, smoking, and inadequate diet must also be acting in the Japanese-Brazilian population.
\end{abstract}

Food Habits; Nutritional Status; Mortality; Transients and Migrants; Risk Factors

\section{Introduction}

Scientific interest has focused on the observation that migrant populations show distinct mortality patterns (when compared to the profile of residents in their place of origin) due to changes in habits and customs in the process of adapting to their new environment. Based on previous studies, the significant socio-cultural changes have shown that this is a high-risk population for developing chronic non-communicable diseases. Diet is an important environmental factor that differs greatly between regions. Thus, Japanese who at some stage in their lives have migrated to culturally distinct environments have merited special attention in order to elucidate whether the differences detected in mortality are due to genetic or environmental factors 1,2,3,4 .

In the Japanese-Brazilian community, ischemic heart disease and diabetes mellitus are the greatest causes of mortality 2,4 . Impaired glucose tolerance, considered a pre-diabetic state, causes an increase in the risk of both all-cause and cardiovascular mortality and is also an important predictor of type- 2 diabetes mellitus ${ }^{5}$. As in the general adult population, mortality increases with age in persons with type- 2 diabetes mellitus. However, in diabetic individuals the force of mortality is double that observed in those without the disease. The increased mortality is believed to occur not only because of macro and microvascular complications, but also due to the association 
with other disease conditions like obesity, arterial hypertension, and dyslipidemia 6 .

The main staple in traditional Japanese diet is rice, with complementary foodstuffs like vegetables, mushrooms, algae, and soybeans and soy products. The average diet consists of $15 \%$ protein, $17 \%$ fat, and $61 \%$ carbohydrate. In the process of migrating to other countries, the Japanese incorporate bread, grains, meat, dairy products, snacks, and soft drinks into their diet. Meanwhile, they stop consuming soybeans and soy products, fish, and fresh fruit. In Japanese Brazilians, the average diet consists of $15 \%$ protein, $32 \%$ fat, and $53 \%$ carbohydrate 7 . Thus, Western diet could be one among other factors in the hypothesis of the unfavorable impact of the environment in the accumulation of abdominal fat and glucose intolerance, observed in Asians who have migrated to the Americas 8,9.

Various studies indicate that high consumption of saturated fat is associated with increased risk of developing cardiovascular disease, while increased intake of polyunsaturated and monounsaturated fat is associated with a reduction in this risk. High intake of saturated fat can induce insulin resistance and thus worsen blood glucose control 10,11.

Obesity is another relevant factor for the predisposition to type- 2 diabetes mellitus, arterial hypertension, dyslipidemia, and cardiovascular diseases. In all regions of Brazil, significant portions of the adult population display overweight and obesity $12,13,14,15,16,17$. In 1996, according to findings by Franco 18, the prevalence of obesity among Japanese-Brazilian women was approximately $40 \%$, similar to that of the urban Brazilian population. For men, the prevalence rates were higher than those of the urban Brazilian population and increased from the first to the second generation $(34.6 \%$ and $45.7 \%$, respectively).

Anthropometry has been widely used in epidemiological studies to assess body composition, due to its low cost and ease of execution 19 .

Studies that aim to assess the risk of developing chronic diseases should consider at least three aspects in adults: the relationship between weight and height, as calculated by the Quetelet or body mass index (BMI), waist circumference, and weight gain during adult life 20 .

BMI indicates the total body mass and is related to an increase in morbidity and mortality at levels less than $18.5 \mathrm{~kg} / \mathrm{m}^{2}$ and greater than $25 \mathrm{~kg} / \mathrm{m}^{2}$ for infectious and chronic diseases, respectively $18,21,22$. BMI is influenced by various factors, including the effect of body build $16,19,23,24$. Meanwhile waist circumference is able to provide an estimate of abdominal fat, which in turn is correlated with the amount of intra-abdominal adipose tissue 4,16,25,26. Weight changes are also known to relate to age; individuals who gain more than $10 \%$ weight from the age of 20 until middle age significantly increase their odds of developing arterial hypertension, dyslipidemia, and hyperinsulinemia 11,27.

Brazil has the largest ethnic Japanese population outside of Japan, estimated in 1988 at $1,168,000$. Of these, half live in the State of São Paulo. Japanese colonization of the county of Bauru in northwestern São Paulo State began in 1914 , especially in the rural area; currently only $11 \%$ of the immigrant population still lives in the countryside, with the majority having moved to the cities $7,27,28$

The aim of this study was to verify associations between all-cause mortality and nutritional variables in a Japanese-Brazilian cohort.

\section{Material and method}

\section{Study population}

In 1993, the Japanese-Brazilian Diabetes Study Group (JBDSG), a group of researchers from the Departmento de Medicina Preventiva, Escola Paulista de Medicina, Universidade Federal de São Paulo (EPM/UNIFESP) and other institutions, launched a research project with the aim of studying the occurrence of glucose intolerance and associated diseases in the first and secondgeneration Japanese-Brazilian population in the county of Bauru, São Paulo State. At the time, a census was performed of the nikkei population (Japanese-born and their descendents). The total population identified was approximately 3 thousand, of whom $12 \%$ were isseis or first generation (born in Japan), 39\% niseis or second generation (born in Brazil but whose parents were born in Japan), 30\% sanseis or third generation, and $19 \%$ mixed-race 8,27 .

Of the 1,137 Japanese-Brazilians living in the urban area and ranging from 40 to 79 years of age, all of the isseis $(\mathrm{n}=284)$ and a sample of one-third of the niseis $(\mathrm{n}=467)$ were invited to participate in the study. The selection process for the second-generation individuals was based on a list of names in alphabetical order, selecting one out of three individuals. The percentage of persons who did not reply to the invitation was $15.8 \%$ and $12.6 \%$ of isseis and niseis, respectively, thus yielding a total sample of 647 (37.3\% first generation and $62.7 \%$ second generation). Details on the characteristics and recruitment of the individuals have been described previously $1,28,29,30$. No statistically significant differences 
were observed in relation to gender or age between participants and non-participants in either generation $1,27,29,30,31,32$.

\section{Data collection}

The first contact with study subjects was by telephone, when they were informed of the study objective. After providing written consent, participants were interviewed at home by trained interviewers, using a standard questionnaire, including personal, socio-demographic, socioeconomic, cultural, and biological data (gender, age, chronic diseases, particularly hypertension and dyslipidemia, and smoking). Information on physical activity was obtained through the questionnaire, considering the type, duration, and frequency of activities during work and leisure time, in which the individuals themselves reported whether they considered their activity (work or leisure) light, moderate, heavy, or very heavy. These data were later grouped into just two categories (heavy/very heavy versus other).

In 1993, habitual food consumption was obtained using a modified food frequency questionnaire (FFQ) including typical Brazilian and Japanese recipes. The modified FFQ followed a format adapted from Tsunehara et al. 33 with Japanese-Americans, quantifying the intake of 177 foods in the previous two months. Chemical composition of the diet was calculated using a software program developed by the Health Information Technology Department, EPM/UNIFESP (Anção MS, Cuppari L, Tudisco ES, Draibe SA, Sigulem D. Nutritional Support Program, version 2.5).

The target nutrients for this study were macronutrients (carbohydrate, protein, saturated and unsaturated fat), fiber, sodium, cholesterol, and sugars, expressed in grams and adjusted for total calories according to the residue method suggested by Willett 19. Alcohol consumption was also studied. Data were used from the diet of the 526 participating individuals (living and deceased).

Weight and height were obtained during the physical examination with participants wearing light clothing and no shoes. Weight was measured using a digital scale with a capacity of $200 \mathrm{~kg}$, accurate to $100 \mathrm{~g}$. Height was measured with a manual stadiometer attached to the wall, with a capacity of $2 \mathrm{~m}$, accurate to $1 \mathrm{~cm}$, with the individual standing erect, heels together, and head straight. BMI was calculated as weight (in $\mathrm{kg}$ ) divided by height squared (in meters). Waist and hip circumferences were measured with a non-flexible tape measure at the navel and tro- chanter, respectively, with subjects standing 8,16. The rate and percentage of weight gain or loss since 20 years of age were calculated as:

Rate of weight $=\underline{\text { (weight in } 1993-\text { weight at } 20 \text { years) }}$ gain (or loss) $=\frac{\text { (age in } 1993-20 \text { years) }}{\text { (a) }}$

and

(weight in 1993 -

$\begin{aligned} & \text { Percentage of } \\ & \text { weight gain (or loss) }\end{aligned}=\frac{\text { weight at } 20 \text { years) } \times 100}{\text { weight at } 20 \text { years }}$

Arterial pressure was measured three times by trained physicians with participants sitting in a quiet setting, after resting for ten minutes, using a random-zero sphygmomanometer. The mean of the last two measurements was used to express blood pressure. Individuals with systolic arterial pressure from 120 to $139 \mathrm{mmHg}$ and diastolic pressure from 80 to $89 \mathrm{mmHg}$ were considered pre-hypertensive, those with systolic pressure greater than $140 \mathrm{mmHg}$ or diastolic greater than $90 \mathrm{mmHg}$ were considered hypertensive, as well as those who reported use of anti-hypertensive medication 34 .

Blood samples were take after ten hours of fasting and again two hours after ingesting $75 \mathrm{~g}$ of glucose for various measurements, including blood glucose and lipid profile (fasting). The glucose was administered to non-diabetics and those reporting a previous diagnosis of diabetes mellitus, but with capillary glucose less than 200mg/dL. Participants on insulin therapy were excluded from the glucose tolerance test. Blood glucose values were determined by the glucoseoxydase method. WHO criteria (1999) 32 were used to classify individuals according to glucose tolerance. Individuals with fasting blood glucose $<110 \mathrm{mg} / \mathrm{dL}$ and two-hour glucose $<140 \mathrm{mg} / \mathrm{dL}$ were classified as normal, those with fasting glucose $\geq 110$ and $<126 \mathrm{mg} / \mathrm{dL}$ and two-hour glucose $<140 \mathrm{mg} / \mathrm{dL}$ were considered as having altered fasting blood glucose, and those with fasting glucose $<126 \mathrm{mg} / \mathrm{dL}$ and two-hour glucose from 140 to $200 \mathrm{mg} / \mathrm{dL}$ were classified as having impaired glucose tolerance, and those with fasting glucose $\geq 126 \mathrm{mg} / \mathrm{dL}$ or two-hour glucose $\geq 200 \mathrm{mg} / \mathrm{dL}$ or on medication for diabetes were classified as diabetics.

Total and partial cholesterol and triglycerides were measured using the enzymatic method. Dyslipidemia was defined as total cholesterol $>200 \mathrm{mg} / \mathrm{dL}$ or triglycerides $>150 \mathrm{mg} / \mathrm{dL}$, or HDL-cholesterol < 40mg/dL, or LDL-cholesterol $>130 \mathrm{mg} / \mathrm{dL}$ for both sexes 35 .

The study protocol was approved by the UNIFESP Research Ethics Committee. 


\section{Statistical analysis}

Point and interval mortality rates were estimated with 95\% confidence interval and $\mathrm{p}<0.05$. Student's t-test was used to compare the mean values observed in 1993, for the metabolic, anthropometric, and dietary variables between living and deceased individuals. The Cox model was used to estimate the odds between the observed all-cause mortality rates for the anthropometric and dietary variables, separately. The principal target exposure variables were level of macronutrients, fiber, alcohol, sodium, cholesterol, and sugars in the habitually consumed diet (as reported in 1993), nutritional status in 1993 (BMI, central obesity), and weight gain or loss since 20 years of age. Hazard ratios were also adjusted for gender (male/female), age (in years), generation (second versus first), physical activity (other versus heavy/very heavy), arterial pressure (systolic and diastolic, in $\mathrm{mmHg}$ ), degree of glucose tolerance ("dummy": normal glucose tolerance, altered fasting blood glucose, impaired glucose tolerance, and diabetes mellitus), presence of dyslipidemia (yes/no), and smoking (smoker/ non-smoker).

To finalize the analysis, a model was constructed including all the control and diet variables. Nutrients that contributed to explaining mortality were kept in the final model.

The data analysis used Stata 7.0 (Stata Corp., College Station, USA).

\section{Results}

In the second phase of the study, 71 deaths had been recorded among the 647 participants from the first phase, from March 1993 to August 2001. Date and cause of death were obtained from death certificates. In 1993, an oral glucose tolerance test had classified $59.7 \%$ as having normal glucose tolerance, $3.3 \%$ as altered fasting glucose, $14.5 \%$ as impaired glucose tolerance, and $22.6 \%$ as diabetes mellitus according to 1999 WHO criteria 32 .

During eight years of follow-up there were 71 deaths $(10.8 \%)$, the highest proportions of which in males (62\%) and in the 60-90-year age group (78.9\%), independently of generation. Crude mortality rates were 21.4 and $11.7 / 1,000$ personyears for men and women, respectively. Regardless of the degree of glucose tolerance, vascular diseases (cardiovascular disease, myocardial infarction) and cancer were the principal causes of death among these Japanese-Brazilians (56.1 and $21.2 \%$ respectively), comprising $77.3 \%$ of the total.
Table 1 shows the mean values and percentages of socio-demographic, biological, and nutritional variables according to the individual's condition at the end of the study. The proportion of smokers, sedentary individuals, and those with diabetes and hypertension was greater among individuals who had died during the study period. Mean age was also higher among the individuals who died. Unexpectedly, the percentage and rate of weight gain were higher among individuals who remained alive.

Table 2 presents the mean dietary intake values (crude and adjusted for total dietary calories) according to condition at the end of the study. No statistically significant differences were observed between the mean values for habitual intake of various nutrients, comparing living and deceased individuals.

Table 3 shows the mortality rates (per thousand person-years) for all causes and the hazard ratios (adjusted for the control variables), according to tertiles for each nutritional variable separately. Unexpectedly, higher cholesterol intake was associated with lower odds of dying (third versus first tertiles: mortality hazard ratio $[\mathrm{MHR}]=0.22$; 95\%CI: 0.06-0.82). Individuals with greater weight gain rates also showed higher odds of dying (second versus first tertile: $\mathrm{MHR}=70.9$; 95\%CI: 1.30-38.81).

Table 4 shows the mortality hazard ratios by tertile for the diet variables adjusted by gender, smoking, age, and weight gain rate simultaneously. In the initial model, the higher the protein intake, the lower the odds of dying $(\mathrm{MHR}=0.20$; 95\%CI: 0.00-0.94). In the final model, there was an inverse relationship between higher carbohydrate intake and mortality (third versus first tertile: $\mathrm{MHR}=0.04 ; 95 \% \mathrm{CI}: 0.00-0.41$ ). The same was true for cholesterol intake (second versus first tertile: $\mathrm{MHR}=0.08$; 95\%CI: 0.00-0.62; (third versus first tertile: $\mathrm{MHR}=0.01 ; 95 \% \mathrm{CI}: 0.00$ $0.17)$.

\section{Discussion}

This study showed an association between mortality and the variables age, physical activity, smoking, diabetes mellitus or hypertension, and carbohydrate and cholesterol intake.

It is well known that the older the individual, the greater the odds of dying. According to our data, individuals who died during the study period were older on average than those who remained alive.

The literature highlights the benefits of physical activity as a protective factor against death. Regular physical activity is known to increase in- 
Percentages or mean values of socio-demographic, biological, and nutritional variables according to condition at end of study among Japanese-Brazilians in Bauru, São Paulo State, Brazil.

\begin{tabular}{|c|c|c|c|}
\hline \multirow[t]{2}{*}{ Variable (in 1993) } & \multicolumn{2}{|c|}{ Condition n 2001} & \multirow[t]{2}{*}{$p$ * } \\
\hline & Living ( $N=647)$ & Deceased $(N=71)$ & \\
\hline$\%$ Males (females) & $48.1(51.9)$ & $49.3(50.7)$ & 0.847 \\
\hline$\%$ 1st-generation (2nd-generation) & $36.8(63.2)$ & $47.3(52.7)$ & 0.502 \\
\hline \% Smokers (non-smokers) & $27.1(72.9)$ & $47.8(52.2)$ & 0.000 \\
\hline$\%$ Other (versus heavy/very heavy) physical activity & $66.4(33.6)$ & $81.2(18.8)$ & 0.036 \\
\hline \% With (without) central obesity & $52.6(47.4)$ & $56.3(43.7)$ & 0.553 \\
\hline$\%$ BMI $(\mathrm{kg} / \mathrm{m} 2)$ & & & 0.225 \\
\hline$<18.5$ & 2.2 & 6.0 & \\
\hline $18.5-24.9$ & 56.3 & 56.7 & \\
\hline $25-29.9$ & 32.9 & 32.8 & \\
\hline$\geq 30$ & 8.6 & 4.5 & \\
\hline$\%$ With (without) diabetes mellitus & $20.0(51.7)$ & $38.6(35.3)$ & 0.008 \\
\hline$\%$ With (without) arterial hypertension & $29.9(70.1)$ & $46.4(53.6)$ & 0.006 \\
\hline \% With (without) dyslipidemia & $79.9(20.1)$ & $89.6(10.4)$ & 0.105 \\
\hline Age (years) & 63.5 & 68.5 & 0.006 \\
\hline BMI $\left(\mathrm{kg} / \mathrm{m}^{2}\right)$ & 24.5 & 24.1 & 0.205 \\
\hline Waist circumference $(\mathrm{cm})$ & 85.8 & 85.9 & 0.450 \\
\hline Systolic arterial pressure $(\mathrm{mmHg})$ & 130.5 & 142.1 & 0.000 \\
\hline Diastolic arterial pressure $(\mathrm{mmHg})$ & 80.0 & 80.2 & 0.466 \\
\hline Fasting blood glucose (mg/dL) & 106.5 & 118.4 & 0.008 \\
\hline 2-hour blood glucose (mg/dL) & 137.1 & 161.3 & 0.007 \\
\hline$\%$ Weight gain since 20 years of age & 14.2 & 6.7 & 0.002 \\
\hline Mean weight gain since 20 years of age & 0.2 & 0.1 & 0.001 \\
\hline
\end{tabular}

BMI: body mass index.

* Chi-square or Student's t-test.

sulin turnover (due to greater liver uptake and improved sensitivity of peripheral receptors), to decrease adiposity, and to improve insulin sensitivity 36 . The methods used by most studies to estimate physical activity have been criticized for their imprecision. In this study, despite the "gross" estimation, the relationship between increased mortality and limited physical activity was statistically significant. Our findings are consistent with those of Lahti-Koski et al. 37 , i.e., that inactive individuals show greater risk of dying. Physical activity is recommended as a way of supplementing dietary treatments for overweight individuals, not only by reducing excess weight itself but also by decreasing fat volume and improving lipid profile 38,39 .

The current study is consistent with the literature in showing excess mortality, as compared to the general population, in individuals with some chronic non-communicable disease 31,39,40. Cardiovascular disease is the main cause of death in many countries. Various studies have shown the harmful effect of arterial hypertension, dysplipidemia, and diabetes mellitus on the circulatory system; these same diseases have insulin resistance in common and comprise the metabolic syndrome 41 . Other cohort studies on Asian populations have indicated that pre-diabetic individuals have an increased risk of both all-cause and cardiovascular mortality $42,43,44$.

In the current study, increased weight gain rate indicated greater risk of death. Obese individuals with type- 2 diabetes mellitus are known to present a $15 \%$ to $30 \%$ greater risk of dying as compared to those with normal weight 45 . Studies with the general population have shown that weight gain and loss correlate with mortality $46,47,48,49$. According to Chaturvedi et al. 39 , the relationship between weight changes and mortality varied according to initial weight. Thus, weight loss in persons with $\mathrm{BMI} \leq 29 \mathrm{~kg} / \mathrm{m}^{2}$ was associated with twice or three times the risk of death as compared to those who maintained stable weight $\left(B M I<26 \mathrm{~kg} / \mathrm{m}^{2}\right.$ : mortality rate 
Table 2

Mean food intake values (means and adjusted for total dietary calories) according to condition at end of study in Japanese-Brazilians in Bauru, São Paulo State, Brazil.

\begin{tabular}{|c|c|c|c|c|c|c|}
\hline \multirow[t]{4}{*}{ Variables } & \multicolumn{4}{|c|}{ Condition } & \multicolumn{2}{|c|}{ Statistic } \\
\hline & \multicolumn{2}{|c|}{ Living ( $N=478)$} & \multicolumn{2}{|c|}{ Deceased $(N=48)$} & \multirow[t]{3}{*}{ Student's t-test *** } & \multirow[t]{3}{*}{$p^{\star \star \star}$} \\
\hline & Mean & Adjusted & Mean & Adjusted & & \\
\hline & & (for total calories) & & (for total calories) & & \\
\hline Calories (kcal) & 2.968 .0 & - & 2.969 .4 & & 0.01 & 0.496 \\
\hline Protein (g) & 107.5 & 107.4 & 104.4 & 104.2 & 1.00 & 0.158 \\
\hline Lipids (g) & 108.5 & 128.7 & 103.6 & 123.7 & 1.14 & 0.127 \\
\hline Carbohydrates (g) & 385.8 & 385.7 & 404.1 & 403.8 & 1.47 & 0.071 \\
\hline Fiber (g) & 7.6 & 7.6 & 8.3 & 8.3 & 1.29 & 0.098 \\
\hline Alcohol (g) & 14.6 * & 13.6 * & 12.4 ** & 10.4 ** & 1.00 & 0.158 \\
\hline Sodium (mg) & 5.636 .2 & 5.636 .3 & 5.165 .7 & 5.163 .3 & 0.97 & 0.166 \\
\hline \multicolumn{7}{|l|}{ Fatty acids (g) } \\
\hline Saturated & 36.1 & 36.0 & 34.7 & 34.6 & 0.81 & 0.207 \\
\hline Polyunsaturated & 18.5 & 18.4 & 18.0 & 17.9 & 0.45 & 0.327 \\
\hline Monounsaturated & 26.9 & 3.2 & 27.8 & 3.2 & 1.02 & 0.153 \\
\hline Cholesterol (mg) & 369.7 & 5.6 & 389.2 & 5.6 & 0.15 & 0.442 \\
\hline Sugars (g) & 17.1 & 17.1 & 15.4 & 15.4 & 1.06 & 0.144 \\
\hline
\end{tabular}

${ }^{\star} \mathrm{n}=240$;

** $\mathrm{n}=23$;

$\star \star \star$ Student's t-test was used for dietary variables adjusted for total dietary calories.

Table 3

All-cause mortality rates (per thousand person-years) and hazard ratios according to dietary variable tertiles (adjusted for total dietary calories) and percentage weight gain (or loss) in Japanese-Brazilians, Bauru, São Paulo State, Brazil.

\begin{tabular}{|c|c|c|c|c|c|c|}
\hline \multirow[t]{3}{*}{ Variables } & \multicolumn{2}{|c|}{ Nutrient mean } & \multicolumn{2}{|c|}{ Mortality rate } & \multirow{3}{*}{$\begin{array}{l}\text { Hazard ratio } \\
\text { (between two } \\
\text { generations) }\end{array}$} & \multirow[t]{3}{*}{$95 \% \mathrm{Cl}$} \\
\hline & $1 \underline{a}$ & $2 \underline{a}$ & $1 \underline{a}$ & $2 \underline{a}$ & & \\
\hline & Generation & Generation & Generation & Generation & & \\
\hline \multicolumn{7}{|l|}{ Calories (Kcal) } \\
\hline 1st tertile & $2,001.5$ & $2,042.7$ & 24.8 & 6.9 & 1.00 & \\
\hline 2nd tertile & $2,800.5$ & $2,848.7$ & 16.0 & 12.4 & 1.26 & $0.38-4.19$ \\
\hline 3rd tertile & $4,111.5$ & $4,031.3$ & 16.2 & 8.6 & 1.31 & $0.40-4.24$ \\
\hline \multicolumn{7}{|l|}{ Protein (g) } \\
\hline 1st tertile & 68.3 & 68.2 & 19.6 & 13.3 & 1.00 & \\
\hline 2nd tertile & 100.1 & 100.7 & 18.3 & 5.6 & 0.36 & $0.10-1.37$ \\
\hline 3rd tertile & 153.7 & 151.8 & 19.2 & 9.0 & 0.74 & $0.26-2.11$ \\
\hline \multicolumn{7}{|l|}{ Lipids (g) } \\
\hline 1st tertile & 64.7 & 63.8 & 21.7 & 13.5 & 1.00 & \\
\hline 2nd tertile & 98.4 & 99.8 & 18.5 & 8.4 & 0.73 & $0.24-2.23$ \\
\hline 3rd tertile & 160.5 & 160.3 & 16.0 & 6.6 & 0.43 & $0.14-1.33$ \\
\hline \multicolumn{7}{|c|}{ Carbohydrate (g) } \\
\hline 1st tertile & 255.5 & 251.7 & 19.2 & 8.1 & 1.00 & \\
\hline 2nd tertile & 374.1 & 368.0 & 10.4 & 5.4 & 0.73 & $0.18-2.96$ \\
\hline 3rd tertile & 544.1 & 536.2 & 25.3 & 15.1 & 1.71 & $0.60-4.89$ \\
\hline \multicolumn{7}{|l|}{ Fiber (g) } \\
\hline 1st tertile & 4.3 & 4.0 & 24.0 & 3.8 & 1.00 & \\
\hline 2nd tertile & 6.7 & 6.7 & 19.6 & 6.8 & 1.81 & $0.47-6.98$ \\
\hline 3rd tertile & 12.8 & 11.2 & 15.7 & 19.2 & 2.78 & $0.82-9.43$ \\
\hline
\end{tabular}

(continue) 


\begin{tabular}{|c|c|c|c|c|c|c|}
\hline \multirow{3}{*}{$\begin{array}{l}\text { Variables } \\
\qquad \text { Generation }\end{array}$} & \multicolumn{2}{|c|}{ Nutrient mean } & \multicolumn{2}{|c|}{ Mortality rate } & \multirow{3}{*}{$\begin{array}{l}\text { Hazard ratio } \\
\text { (between two }\end{array}$} & \multirow[t]{3}{*}{$95 \% \mathrm{Cl}$} \\
\hline & $1 \underline{a}$ & $2 a$ & $1 \underline{a}$ & $2 a$ & & \\
\hline & Generation & Generation & Generation & generations) & & \\
\hline \multicolumn{7}{|l|}{ Alcohol (g) } \\
\hline 1st tertile & 0.1 & 0.1 & 19.6 & 13.3 & 1.00 & \\
\hline 2nd tertile & 3.6 & 2.9 & 18.3 & 5.6 & 0.36 & $0.10-1.37$ \\
\hline 3rd tertile & 38.9 & 42.2 & 19.2 & 9.0 & 0.74 & $0.26-2.11$ \\
\hline \multicolumn{7}{|l|}{ Sodium (mg) } \\
\hline 1st tertile & $2,400.3$ & $2,506.4$ & 28.8 & 11.8 & 1.00 & \\
\hline 2nd tertile & $4,765.1$ & $4,654.9$ & 25.5 & 5.3 & 0.72 & $0.23-2.26$ \\
\hline 3rd tertile & $10,801.4$ & $8,675.3$ & 9.9 & 11.2 & 0.73 & $0.24-2.24$ \\
\hline \multicolumn{7}{|l|}{ Fatty acids (g) } \\
\hline \multicolumn{7}{|l|}{ Saturated } \\
\hline 1st tertile & 20.1 & 19.6 & 20.7 & 9.4 & 1.00 & \\
\hline 2nd tertile & 32.0 & 33.5 & 14.0 & 11.9 & 1.96 & $0.60-6.47$ \\
\hline 3rd tertile & 56.2 & 56.1 & 22.6 & 6.7 & 1.19 & $0.31-4.50$ \\
\hline \multicolumn{7}{|l|}{ Polyunsaturated } \\
\hline 1 st tertile & 10.5 & 10.5 & 23.4 & 6.3 & 1.00 & \\
\hline 2nd tertile & 15.9 & 16.0 & 16.4 & 10.3 & 1.72 & 0.49-6.01 \\
\hline 3rd tertile & 25.8 & 28.8 & 18.5 & 12.1 & 1.69 & $0.49-5.82$ \\
\hline \multicolumn{7}{|c|}{ Monounsaturated } \\
\hline 1st tertile & 14.9 & 14.9 & 18.7 & 9.6 & 1.00 & \\
\hline 2nd tertile & 24.1 & 23.6 & 19.7 & 6.0 & 1.03 & $0.27-3.90$ \\
\hline 3rd tertile & 43.2 & 40.8 & 18.6 & 12.1 & 1.59 & $0.48-5.25$ \\
\hline \multicolumn{7}{|l|}{ Cholesterol (mg) } \\
\hline 1st tertile & 190.1 & 192.4 & 10.8 & 16.0 & 1.00 & \\
\hline 2nd tertile & 335.1 & 342.3 & 26.9 & 6.7 & 0.46 & $0.15-1.36$ \\
\hline 3rd tertile & 604.0 & 567.9 & 20.4 & 5.6 & 0.22 & $0.06-0.83$ \\
\hline \multicolumn{7}{|l|}{ Sugars (g) } \\
\hline 1st tertile & 7.3 & 6.6 & 18.3 & 13.5 & 1.00 & \\
\hline 2nd tertile & 15.2 & 15.1 & 17.8 & 8.4 & 0.35 & $0.11-1.17$ \\
\hline 3rd tertile & 28.9 & 29.0 & 22.5 & 7.3 & 0.48 & $0.16-1.45$ \\
\hline \multicolumn{7}{|l|}{ \% Weight gain } \\
\hline 1st tertile & 3.2 & 3.3 & 34.5 & 13.8 & 1.00 & \\
\hline 2nd tertile & 13.5 & 13.9 & 22.1 & 11.1 & Indeterminate & \\
\hline 3rd tertile & 34.0 & 35.2 & 3.5 & 10.4 & Indeterminate & \\
\hline \multicolumn{7}{|l|}{ Weight gain rate } \\
\hline 1st tertile & 0.1 & 0.1 & 33.8 & 9.1 & 1.00 & \\
\hline 2nd tertile & 0.3 & 0.3 & 3.5 & 18.2 & 7.55 & $1.35-42.29$ \\
\hline 3rd tertile & 0.5 & 0.6 & 6.8 & 6.8 & 0.68 & 0.09-5.01 \\
\hline
\end{tabular}

* Adjusted for gender, age, generation, physical activity, and smoking.

$[\mathrm{MR}]=3.05 ; 95 \% \mathrm{CI}: 1.26-7.36 ; \mathrm{BMI}=26-29 \mathrm{~kg} /$ $\left.\mathrm{m}^{2}: \mathrm{MR}=2.02 ; 95 \% \mathrm{CI}: 1.00-4.08\right)$. Meanwhile in more obese individuals $\left(\mathrm{BMI}>29 \mathrm{~kg} / \mathrm{m}^{2}\right)$, weight loss was associated with a non-significant reduction in mortality (BMI $\geq 29 \mathrm{~kg} / \mathrm{m}^{2}$ : $\mathrm{MR}=0.84$; 95\%CI: $0.40-1.74)$. Thus, a plausible hypothesis is that individuals who died had gained weight at a greater rate, leading to overweight.

Various studies have shown a relationship between qualitative and quantitative dietary characteristics and chronic diseases 50,51,52. In Bra- zil, recent decades have witnessed a downward trend in the consumption of grains and tubercles and the substitution of carbohydrates with lipids and plant protein with animal protein 53 . There is evidence that these changes are associated with increased obesity and various chronic and degenerative diseases 54 . According to Hujibregts et al. 55, 20-year mortality in men with a healthier diet (rich in fruits and vegetables and complex carbohydrates and poor in saturate fat) was lower than in individuals with less healthy diets. After 
All-cause mortality hazard ratios (95\% confidence interval) according to tertiles for socio-demographic, biological, and nutritional variables in Japanese-Brazilians in Bauru, São Paulo State, Brazil.

\begin{tabular}{|c|c|c|}
\hline \multirow[t]{2}{*}{ Variables } & \multicolumn{2}{|c|}{ Hazard ratios $(95 \% \mathrm{Cl})$} \\
\hline & Initial model & Final model \\
\hline Gender & $2.73(0.28-26.73)$ & $2.24(0.59-8.52)$ \\
\hline Smoking & $99.21(1.58-6.212 .17)$ & $7.25(1.61-32.62)$ \\
\hline Age $1.23(1.04-1.46)$ & $1.16(1.06-1.27)$ & \\
\hline \multicolumn{3}{|l|}{ Weight gain rate } \\
\hline 1st tertile & 1.00 & 1.00 \\
\hline 2nd tertile & 33.57 (1.04-1.085.23) & $7.94(1.37-45.87)$ \\
\hline 3rd tertile & $2.09(0.04-123.34)$ & $0.43(0.05-3.85)$ \\
\hline \multicolumn{3}{|l|}{ Calories (Kcal) } \\
\hline 1st tertile & 1.00 & \\
\hline 2nd tertile & $7.62(0.14-425.04)$ & - \\
\hline 3rd tertile & $2.47(0.07-82.90)$ & - \\
\hline \multicolumn{3}{|l|}{ Protein (g) } \\
\hline 1st tertile & 1.00 & \\
\hline 2nd tertile & $0.20(0.00-0.94)$ & \\
\hline 3rd tertile & & - \\
\hline Lipids (g) & & - \\
\hline 1st tertile & 1.00 & \\
\hline 2nd tertile & $0.42(0.00-190.08)$ & - \\
\hline 3rd tertile & $0.33(0.00-218.05)$ & - \\
\hline \multicolumn{3}{|l|}{ Carbohydrates (g) } \\
\hline 1st tertile & 1.00 & 1.00 \\
\hline 2nd tertile & $0.74(0.21-2.63)$ & $0.14(0.02-1.16)$ \\
\hline 3rd tertile & 0.00 (indeterminate) & $0.04(0.00-0.41)$ \\
\hline \multicolumn{3}{|l|}{ Fiber (g) } \\
\hline 1 st tertile & 1.00 & \\
\hline 2nd tertile & $0.83(0.04-18.55)$ & - \\
\hline 3rd tertile & $13.58(0.39-469.79)$ & - \\
\hline \multicolumn{3}{|l|}{ Alcohol (g) } \\
\hline 1st tertile & 1.00 & \\
\hline 2nd tertile & Indeterminate & - \\
\hline 3rd tertile & Indeterminate & - \\
\hline \multicolumn{3}{|l|}{ Sodium (mg) } \\
\hline 1 st tertile & 1.00 & \\
\hline 2nd tertile & $0.01(0.00-1.04)$ & - \\
\hline 3rd tertile & $0.29(0.02-4.64)$ & - \\
\hline \multicolumn{3}{|l|}{ Fatty acids (g) } \\
\hline \multicolumn{3}{|l|}{ Saturated } \\
\hline 1st tertile & 1.00 & - \\
\hline 2nd tertile & $1.76(0.02-136.92)$ & - \\
\hline 3rd tertile & $5.17(0.03-941.30)$ & \\
\hline \multicolumn{3}{|l|}{ Polyunsaturated } \\
\hline 1st tertile & 1.00 & - \\
\hline 2nd tertile & $0.75(0.05-12.26)$ & - \\
\hline 3rd tertile & $0.23(0.00-30.43)$ & \\
\hline \multicolumn{3}{|l|}{ Monounsaturated } \\
\hline 1st tertile & 1.00 & - \\
\hline 2nd tertile & $14.60(0.10-2.068 .16)$ & \\
\hline 3rd tertile & $301.76(0.76-19.172 .70)$ & - \\
\hline
\end{tabular}

(continue) 


\begin{tabular}{lcc} 
Table 4 (continuation) & & \\
\hline Variables & Initial model & Hazard ratios $(95 \% \mathrm{Cl})$ \\
& & Final model \\
\hline $\begin{array}{l}\text { Cholesterol }(\mathrm{mg}) \\
\text { 1st tertile }\end{array}$ & 1.00 & 1.00 \\
2nd tertile & 0.00 (indeterminate) & $0.08(0.00-0.62)$ \\
3rd tertile & 0.00 (indeterminate) & $0.01(0.00-0.17)$ \\
Sugars (g) & & \\
1st tertile & 1.00 & - \\
2nd tertile & $0.08(0.00-5.10)$ & - \\
3rd tertile & $0.28(0.01-9.15)$ & \\
\hline
\end{tabular}

adjusting for age, smoking, and alcohol intake, the odds of dying were $13 \%$ less among those with a healthy diet.

In this study, higher cholesterol intake was identified as protective against death. A hypothesis for this finding is a possible bias caused by prior diagnosis, i.e., individuals with chronic diseases (diabetes mellitus, cardiovascular, arterial hypertension) may have reduced their cholesterol intake after receiving their diagnosis. The analyses here did not control for use of medication.

In the current study, carbohydrate-rich diet was associated with lower risk of death (hazard ratio $=0.04)$. According to Werner 56, a carbohydrate-poor diet was not necessarily better for weight reduction than a carbohydrate-rich diet. Our study did not analyze the glycemic index for the foodstuffs in the Japanese-Brazilian diet, but it is known that consumption of vegetables and leafy vegetables and whole grains (foods with low glycemic index) have a protective effect in the diet.

Methodological limitations for data collection on eating patterns may have contributed partially to the controversial results. Perfect data collection does not exist, and data collected with a food frequency questionnaire vary according to the interviewee's recall. The questionnaire used in this study analyzed only the last two months of the diet, which may have been inappropriate for investigating long-term mortality risk factors.
In addition, some information was lost when the questionnaires were not filled out correctly. The information used for this study was based on 1993, and behavioral changes taking place during this eight-year period (or until death) were not taken into account.

Meanwhile, the study had the advantage of not having been based on death certificates. In addition, the availability of individual information, including socio-demographic, biological, and nutritional data, allowed simultaneous control of different variables in the statistical analyses.

The findings, even though for a relatively short time period (eight years), confirm the need to adopt measures aimed at controlling chronic diseases, which play an important role in mortality in populations worldwide. Based on the analyses, classical risk factors for mortality such as age, chronic diseases, sedentary lifestyle, smoking, and diet are also at work in the Japanese-Brazilian population currently consuming a Western style diet. Although no single nutrient is capable of preventing or treating diseases, a set of healthy actions and habits can have a strong influence on the prevention of chronic diseases, thereby reducing the mortality associated with them. In this study, the preliminary results did not identify which nutrients led to greater mortality; some nutrients proved protective, but the glycemic index of these foodstuffs was not taken into account. 


\section{Resumo}

O objetivo do estudo foi verificar a existência de associações entre variáveis nutricionais e a mortalidade em uma coorte de nipo-brasileiros. Em 1993, 647 indivíduos foram entrevistados (questionário de freqüência alimentar), submetidos ao exame físico (peso, altura, pressão arterial) e a exames bioquímicos (teste de tolerância oral à glicose). O teste t de Student foi utilizado para comparar valores médios das variáveis de interesse entre vivos e mortos. Obtiveram-se as taxas de mortalidade e razões entre esses coeficientes (brutas e ajustadas) segundo variáveis nutricionais. Observou-se taxa de mortalidade geral de 21,4 e 11,7/mil pessoas-ano para homens e mulheres, respectivamente. Entre os indivíduos que morreram, encontrou-se maior porcentagem de sujeitos diabéticos, sedentários e hipertensos. Após ajuste às variáveis de controle, observou-se maior mortalidade entre os com menor consumo de glícides e colesterol. Conclui-se que os fatores de risco clássicos para mortalidade, como idade, doenças crônicas, sedentarismo, tabagismo e dieta, devem estar atuantes também na população nipo-brasileira.

Hábitos Alimentares; Estado Nutricional; Mortalidade; Migrantes; Fatores de Risco

\section{Contributors}

F. C. Massimino wrote the article. S. G. A. Gimeno participated in the study planning, data collection, statistical analysis, and review of the manuscript. S. R. G. Ferreira contributed to the study planning and data collection. The Japanese-Brazilian Diabetes Study Group contributed to the data collection.

\section{Other members of the Japanese-Brazilian Diabetes Study Group}

N. Barros Jr., M. A. Cardoso, R. C. Chaim, V. D’Almeida, L. J. Franco, H. Harima, A. Hirai, A. T. Hirai, M. Y. Kikuchi, L. K. Matsumura, R. S. Moisés, K. Osiro, N. E. Tomita, K. Wakisaka.

\section{Acknowledgments}

The authors wish to thank all the researchers from the Japanese-Brazilian Diabetes Study Group, who contributed indirectly to this study, and the São Paulo State Research Foundation for a research grant.

\section{References}

1. Gimeno SGA, Ferreira SRG, Franco LJ, Iunes M; Japanese-Brazilian Diabetes Study Group. Comparison of glucose tolerance categories according to World Health Organization and American Diabetes Association diagnostic criteria in a population-based study in Brazil. Diabetes Care 1998; 21:1889-92.

2. Souza RKT, Gotlieb SLD. Mortalidade em migrantes japoneses residentes no Paraná, Brasil. Rev Saúde Pública 1999; 33:262-72.

3. Rodriguez BL, Abbott RD, Fujimoto W, Waitzfelder B, Chen R, Masaki K, et al. The American Diabetes Association and World Health Organization classification for diabetes. Diabetes Care 2002; 25:951-5.

4. Japanese-Brazilian Diabetes Study Group. Diabetes mellitus e doenças associadas. São Paulo: Centro de Estudos de Nipo-brasileiros, Universidade Federal de São Paulo; 2004.

5. Hayashi T, Boyko EJ, Leonetti DL, Marguerite MJ, Laura MN, Kahn SE, et al. Visceral adiposity and the risk of impaired glucose tolerance. Diabetes Care 2003; 26:650-5.
6. Hanis CL, Chu HL, Lawson K, Hewett-Emmett D, Barton SA, Schull Wj, et al. Mortality of Mexican-Americans with NIDDM. Diabetes Care 1993; 16:82-9.

7. Freire RD, Cardoso MA, Shinzato AR, Ferreira SRG. Nutritional status of Japanese-Brazilian subjects: comparison across gender and generation. $\mathrm{Br} \mathrm{J}$ Nutr 2003; 89:705-12.

8. Costa MB, Ferreira SRG, Franco LJ, Gimeno SGA, Iunes M; Japanese-Brazilian Diabetes Study Group. Dietary patterns in a high-risk population for glucose intolerance. J Epidemiol 2000; 10:111-7.

9. Ferreira SRG, Lerario DDG, Gimeno SGA, Sanudo A, Franco LJ. Obesity and central adiposity in Japanese immigrants: role of Western dietary pattern. J Epidemiol 2002; 12:431-8.

10. Williams DE, Knowler WC, Smith CJ, Hanson RL, Roumain J, Saremi A, et al. The effect of Indian or Anglo dietary preference on the incidence of diabetes in Pima Indians. Diabetes Care 2001; 24:8116. 
11. Ley SJ, Metcalf PA, Scragg RKR, Swinburn BA Long-term effects of a reduced fat diet intervention on cardiovascular disease risk factors in individuals with glucose intolerance. Diabetes Res Clin Pract 2002; 63:103-12.

12. Pinheiro ARO, Freitas SFT, Corso ACT. Uma abordagem epidemiológica da obesidade. Rev Nutr 2004; 17:523-33.

13. Gigante DP, Barros FC, Post CLA, Olinto MTA. Prevalência de obesidade em adultos e seus fatores de risco. Rev Saúde Pública 1997; 31:236-46.

14. Boyko EJ, Fujimoto WY, Leonetti DL, Morris LN. Visceral adiposity and risk of type 2 diabetes. Diabetes Care 2000; 23:465-71.

15. Welborn TA, Knuiman MW, Vu HTV. Body mass index and alternative indices of obesity in relation to height, triceps skinfold and subsequent mortality: the Busselton Health Study. Int J Obesity 2000; 24:108-15.

16. Lerario DDG, Gimeno SGA, Franco LJ, Iunes M, Ferreira SRG; Japanese-Brazilian Diabetes Study Group. Excesso de peso e gordura abdominal para a síndrome metabólica em nipo-brasileiros. Rev Saúde Pública 2002; 36:4-11.

17. World Heath Organization. Obesity: preventing and managing the global epidemic. Geneva: World Heath Organization; 1998.

18. Franco LJ. Diabetes in Japanese-Brazilians: influence of acculturation process. Diabetes Res Clin Pract 1996; 34:51-7.

19. Willett WC. Nutritional Epidemiology. 2a Ed. New York: Oxford University Press; 1998.

20. Moon OR, Kim NS, Jang SM, Yoon TH, Kim SO. The relationship between body mass index and the prevalence of obesity-related diseases based on the 1995 National Health Interview Survey in Korea. The International Association for the Study of Obesity. Obes Rev 2002; 3:191-6.

21. World Health Organization. Physical status: the use and interpretation of anthropometry. Geneva: World Health Organization; 1995. (WHO Technical Report Series, 854).

22. Deurenberg-Yap M, Schmidt G, van Staveren WA, Deurenberg P. The paradox of low body mass index and high body fat percentage among Chinese, Malays and Indians in Singapore. Int J Obes Relat Metab Disord 2000; 24:1011-7.

23. Deurenberg P, Deurenberg-Yap M, Guricci S. Asians are different from Caucasians from each other in their body mass index/body fat per cent relationship. The International Association for the Study of Obesity. Obes Rev 2002; 3:141-6.

24. Li G, Chen X, Jang Y, Wang J, Xing X, Yang W, et al. Obesity, coronary heart disease risk factors and diabetes in Chinese: an approach to the criteria of obesity in the Chinese population. The International Association for the Study of Obesity. Obes Rev 2002; 3:167-72.

25. Ko GTC, Chan JNC, Cockram CS, Woo J. Prediction of hypertension, diabetes, dyslipidaemia or albuminuria using simple anthropometric indexes in Hong Kong Chinese. Int J Obes Relat Metab Disord 1999; 23:1136-42.
26. Senti M, Bosh M, Aubó C, Elosua R, Masià R, Marrugat J. Relationship of abdominal adiposity and dyslipemic status in women with a common mutation in the lipoprotein lipase gene. The REGICOR investigators. Atherosclerosis 2000; 150:135-41.

27. Gimeno SGA, Ferreira SRG, Cardoso MA, Franco LJ, Iunes M; Japanese-Brazilian Diabetes Study Group. Weight gain in adulthood and risk of developing glucose tolerance disturbance: a study of a Japanese-Brazilian Population. J Epidemiol 2000; 10:103-10.

28. Centro de Estudos Nipo-Brasileiros. Pesquisa da população descendente de japoneses no Brasil. São Paulo: Centro de Estudos Nipo-Brasileiros; 1998.

29. Ferreira SRG, Iunes M, Franco LJ, Iochida LC, Hirai A, Vivolo MA. Disturbance of glucose and lipid metabolism in first and second generation JapaneseBrazilians. Diabetes Res Clin Pract 1996; 34:59-63.

30. Gimeno SGA, Ferreira SRG, Franco LJ, Harima H, Moisés RCS; Japanese-Brazilian Diabetes Study Group. Cardiovascular mortality in Japanese-Brazilians according to category of glucose tolerance. Diabetes 2002; 51 Suppl 2:A225.

31. Gimeno SGA, Osiro K, Matsumura L, Massimino FC, Ferreira SGF; Japanese-Brazilian Diabetes Study Group. Glucose intolerance and all-cause mortality in Japanese migrants. Diabetes Res Clin Pract 2005; 68:147-54.

32. Alberti KGMM, Zimmet PZ. For the World Health Organization consultation of diabetes mellitus and its complications. Part 1. Diagnosis and classification of DM. Geneva: World Health Organization; 1999.

33. Tsunehara C, Leonetti DL, Fijimoto WY. Diet of second-generation Japanese-American men with and without non-insulin-dependent diabetes. Am J Clin Nutr 1990; 52:731-8.

34. Chobanian AV, Bakris GL, Black HR, Cushman WC, Green LA, Izzo Jr. JL, et al. The Seventh Report of the Joint National Committee on Prevention, Detection, Evaluation, and Treatment of High Blood Pressure: the JNC 7 report. JAMA 2003; 289:256072.

35. Expert Panel on Detection, Evaluation, and Treatment of High Blood Cholesterol in Adults. Executive Summary of The Third Report of the National Cholesterol Education Program (NCEP) Expert Panel on Detection, Evaluation, and Treatment of High Blood Cholesterol in Adults (Adult Treatment Panel III). JAMA 2001; 285:2486-97.

36. Sartorelli DS, Franco LJ. Tendências do diabetes mellitus no Brasil: o papel da transição nutricional. Cad Saúde Pública 2003; 19 Suppl 1:S29-36.

37. Lahti-Koski M, Pietinen P, Heliovaara M, Vartiainen E. Associations of body mass index and obesity with physical activity, food choices, alcohol intake, and smoking in the 1982-1997 FINRISK Studies. Am J Clin Nutr 2002; 75:809-17.

38. Miyatake N, Takanami S, Kawasaki, Y, Fujii M. Relationship between visceral fat accumulation and physical fitness in Japanese women. Diabetes Res Clin Pract 2004; 64:173-9. 
39. Chaturvedi N, Fuller J; The World Multinational Study Group. Mortality risk by body weight and weight change in people with NIDDM. Diabetes Care 1995; 18:766-74.

40. Stamler J, Vaccaro O, Neaton JD, Wentworth D. Diabetes, other risk factors and 12-yr cardiovascular mortality for men screened in the Multiple Risk Factor Intervention Trial. Diabetes Care 1993; 16:434-44.

41. Rosenbaum P, Ferreira SRG. Uma atualização em risco cardiovascular da síndrome metabólica. Arq Bras Endocrinol Metab 2003; 47:220-7.

42. Fijishima M, Kiyohara Y, Kato I, Ohmura T, Iawamoto H, Makayama K, et al. Diabetes and cardiovascular disease in a prospective population survey in Japan: The Hisayana Study. Diabetes 1996; 45 Suppl 3:14-6.

43. Balkau B, Shipley MJ, Janett RJ, Pyorala K, Pyorala M, Forhan A, et al. High blood glucose concentration is a risk factor for mortality in middle-aged non-diabetic men. Diabetes Care 1998; 21:360-7.

44. Tominaga M, Eguchi H, Manaka H, Igarashi K, Kato $\mathrm{T}$, Stekikawa A. Impaired glucose tolerance is a risk factor for cardiovascular disease, but not impaired fasting glucose. Diabetes Care 1999; 22:920-4.

45. Colditz GA, Willet WC, Rotnetzky A, Manson JE. Weight gain as a risk factor for clinical diabetes mellitus in women. Ann Intern Med 1995; 122:4816.

46. Harris T, Cook EF, Garrison R, Higgins M, Kannel W, Goldman L. Body mass index and mortality among nonsmoking older persons. The Framingham Heart Study. JAMA 1988; 259:1520-4.

47. Pamuk ER, Williamson DF, Madans J, Serdula MK, Kleinman JC, Byers T. Weight loss and mortality in a national cohort of adults, 1971-1987. Am J Epidemiol 1992; 136:686-97.
48. Hubert HB, Feinleib M, McNamara PM, Castelli WP. Obesity as an independent risk factor for cardiovascular disease: a 26-year follow-up of participants in the Framingham Heart Study. Circulation 1983; 67:968-77.

49. Andres R, Muller DC, Sorkin JD. Long-term effects of change in body weight on all-cause mortality: a review. Ann Intern Med 1993; 119 Suppl 2:737-43.

50. Cervato AM, Mazzilli RN, Martins IS, Marucci MFN. Dieta habitual e fatores de risco para doenças cardiovasculares. Rev Saúde Pública 1997; 31:227-35

51. Mustad VA, Kris-Etherton PM. Além da redução do colesterol: decifrando os benefícios da intervenção alimentar para doença cardiovascular. Curr Atheroscler Reports Brasil 2001; 1:2-7.

52. Castro LCV, Franceschini SCC, Priore SE, Pelúzio MCG. Nutrição e doenças cardiovasculares: os marcadores de risco em adultos. Rev Nutr 2004; 17:369-77.

53. Instituto Brasileiro de Geografia e Estatística. Pesquisa de Orçamentos Familiares - POF 20022003. Aquisição alimentar domiciliar per capita - Brasil e Grandes Regiões. http://www.ibge.gov. br/home/estatistica/populacao/condicaodevida/ pof/2002aquisicao/default.shtm (accessed on 28/ Sep/2005).

54. Stamler J. Epidemic obesity in the United. Arch Intern Med 1993; 153:1040-4.

55. Huijbregts P, Feskens E, Rasanen L, Fidanza F, Nissinen A, Menotti A, et al. Dietary pattern and 20 year mortality in elderly men in Finland, Italy and the Netherlands: longitudinal cohort study. BJM 1997; 315:13-7.

56. Werner SB. Comparison between weight reduction on a high calorie fat diet and on an isocaloric regimen high in carbohydrate. N Engl J Med 1955; 66:252.

Subbmited on 09/May/2005

Final version resubmitted on 06/Nov/2006

Approved on 05/Dec/2006 